Jakub Polanowski*

\title{
W KWESTII ODPOWIEDZIALNOŚCI RADNEGO ZA PROWADZENIE DZIAŁALNOŚCI Z WYKORZYSTANIEM MIENIA KOMUNALNEGO
}

\section{Wartości chronione}

Życie osoby ludzkiej wpisane jest immanentnie w istnienie społeczności, stanowi ona bowiem naturalną formę życia i rozwoju człowieka. Ta forma nie jest jedynie przejawem „życia stadnego”, charakterystycznego dla świata zwierząt, lecz jej źródło tkwi głębiej, w konieczności rozwoju osobowego, ponieważ poznanie i miłość wiążące się w akt decyzyjny pośredniczy i tłumaczy łączenie się osób w grupy społeczne ${ }^{1}$.

Właściwa tej społecznej inklinacji osoby ludzkiej skłonność w swej istocie uzasadnia takie ukształtowanie podmiotów władzy publicznej, które odpowiada osobowej godności człowieka, zasadzie pomocniczości, zasadzie poszanowania wolności i sprawiedliwości społecznej czy zasadzie współdziałania władz i dialogu społecznego. Realizacji tych zasad upatrywać można w decentralizacji administracji publicznej, pełniącej funkcję zasady ustrojowej, która umożliwia taki sposób or-

Jakub Polanowski - doktor nauk prawnych, Wojewódzki Sąd Administracyjny w Lublinie.

${ }^{1}$ M.A. Krąpiec [w:] M.A. Krąpiec, Wprowadzenie do filozofii, Lublin 2008, s. 319. 
ganizacji aparatu administracyjnego, w jakim organy niższego stopnia nie są podporządkowane organom wyższego stopnia²

W tym kontekście zawiera się jedna z perspektyw badawczych fenomenu samorządu terytorialnego, to właśnie na zasadzie decentralizacji opiera się bowiem wykonywanie przekazanych jednostkom samorządowym zadań i kompetencji z zakresu administracji publicznej. To prowadzi do wniosku, że samorząd terytorialny staje się narzędziem decentralizacji administracji publicznej, spełniając wymóg określony w art. 15 ust. 1 Konstytucji RP ${ }^{3}$.

Spojrzenie na ten fenomen domaga się krytycznego oglądu niektórych instytucji prawnych wiązanych ze stosowaniem prawa. Z tego punktu widzenia interesująca wydaje się analiza jednej ze szczegółowych kwestii dotyczących prawa samorządowego, jaką jest ograniczenie działalności prawnej radnego. W niniejszym artykule kwestia ta rozważana będzie w odniesieniu do przepisów u.s.g.

Stosownie do art. $24 \mathrm{f}$ ust. 1 u.s.g. radni nie mogą prowadzić działalności gospodarczej na własny rachunek lub wspólnie z innymi osobami z wykorzystaniem mienia komunalnego gminy, w której radny uzyskał mandat, a także zarządzać taką działalnością lub być przedstawicielem czy pełnomocnikiem w prowadzeniu takiej działalności.

Odniesienie się do szczegółowych kwestii dotyczących omawianego zagadnienia wymaga zidentyfikowania i precyzyjnego wyodrębnienia wartości, dóbr, które chronić ma wspomniany zakaz. Takiego działania wymaga sama natura odpowiedzialności za czyn. W filozofii o ukierunkowaniu fenomenologicznym wskazuje się trafnie, że bez istnienia wartości pozytywnych i negatywnych oraz bez zachodzących między nimi związków bytowych i związków określa-

2 M. Stahl [w:] System Prawa Administracyjnego, t. 6, Podmioty administrujące, red. R. Hauser, A. Wróbel, Z. Niewiadomski, Warszawa 2011, s. 85 wraz z powołaną literaturą.

3 Z. Niewiadomski [w:] System..., red. R. Hauser, A. Wróbel, Z. Niewiadomski, t. 6, Podmioty..., s. 125 wraz z powołaną literaturą. 
nia „w ogóle nie mogłaby istnieć żadna prawdziwa odpowiedzialność, a także żadne spełnienie postawionych przez nią wymagań"4. Wartości odgrywają zatem szczególną rolę w procesie odczytywania podstaw odpowiedzialności, w tym odpowiedzialności prawnej, co wynika z tego, że z wartości wyprowadzić można normy, które pokazują typy zachowań o różnej mocy normatywnej ${ }^{5}$.

Można więc powiedzieć, że pytania o wartości, o ich treść i cel, stanowią perspektywę rozumienia prawa ${ }^{6}$. Nie należy zatem dziwić się stwierdzeniu, że moralność prawa, będąca jedną z podstawowych wartości prawa, ujawnia się w prawie administracyjnym w konflikcie, jaki powstaje pomiędzy skrajnie pozytywistycznym podejściem do wykładni tego prawa a podejściem zgodnym ze starożytną maksymą, iż prawo jest sztuką stosowania tego, co dobre i słuszne ${ }^{7}$. Zarazem jednym $z$ najistotniejszych elementów aksjologii prawa, w tym prawa administracyjnego, jest racjonalność, która wymaga między innymi, by tworząc prawo, należycie ocenić konkurencyjne rozwiązania prawne i wybrać najbardziej rozsądne.

Stąd to właśnie prawo, ustalając podstawę działań organów administracji publicznej, powinno je formułować tak, aby powodowały racjonalne zachowanie się organów administracyjnych ${ }^{8}$. Pytania o racjonalność w sposób nieodłączny towarzyszyć muszą zatem również wykładni prawa administracyjnego. Racjonalność należy przy tym ujmować przede wszystkim z innej perspektywy, jako zasadę systemową prawa. Ta zasada w demokratycznym państwie prawa nie limituje swobody rozstrzygania sędziów, gdyż racjonalne działanie w granicach prawa służy dobru wspólnemu, zapewnieniu bezpieczeństwa prawnego oraz poczucia sprawiedliwości i słusz-

${ }^{4}$ R. Ingarden, Książeczka o człowieku, Kraków 1987, s. 99.

${ }^{5}$ J. Mariański [w:] Człowiek i jego decyzje, red. K.A. Kłosiński, A. Biela, Lublin 2009, s. 348.

${ }^{6}$ Podobnie ujmują to J. Boć, P. Lisowski [w:] Wartości w prawie administracyjnym, red. J. Zimmermann, Warszawa 2015, s. 19.

7 J. Zimmermann, Aksjomaty prawa administracyjnego, Warszawa 2013, s. 78-79.

${ }^{8}$ J. Zimmermann, Aksjomaty..., s. 88-89. 
ności ${ }^{9}$. Odpowiedzialność w ogólności, a zwłaszcza odpowiedzialność administracyjna, musi zatem opierać się na solidnych fundamentach etycznych, zwłaszcza gdy dotyka ona tak głęboko osoby ludzkiej, jak czyni to władza publiczna, stosując narzędzia - instrumenty odpowiedzialności prawnej. Wśród wszystkich typów odpowiedzialności prawnej niezwykle restrykcyjnie była, zwłaszcza przed 1.06.2017 r., unormowana metoda normowania podstaw odpowiedzialności administracyjnej, odpowiadająca przeważającej w doktrynie koncepcji tzw. odpowiedzialności obiektywnej, zakładającej - jako cechę odróżniającą od innych form odpowiedzialności - odpowiedzialność za rezultat działania osoby ludzkiej, co do zasady bez uwzględnienia strony podmiotowej czynu, to jest między innymi możliwości postawienia zarzutu działania w złej wierze czy nawet zobiektywizowanego podmiotowo kryterium braku możliwości powzięcia przez sprawcę wiedzy o istnieniu podstaw odpowiedzialności za określony czyn - jako okoliczności wpływających na wymiar kary.

Obecnie, na skutek nowelizacji przepisów k.p.a., jaka weszła w życie we wskazanej wyżej dacie ${ }^{10}$, wprowadzono nowe regulacje dotyczące administracyjnych kar pieniężnych, które normują także dyrektywy wymiaru takich kar. Dyrektywy te, jak wynika z art. 189d k.p.a., odnoszą się między innymi do wagi i okoliczności naruszenia prawa, stopnia przyczynienia się strony do naruszenia prawa, dobrowolnych działań strony zmierzających do naprawienia popełnionego uchybienia czy nawet warunków osoby fizycznej, na którą taka kara jest nakładana. Unormowanie to, moim zdaniem, będzie miało istotny wpływ na model odpowiedzialności administracyjnej w Polsce. Niewątpliwie bowiem, co należy odnotować, regulacja ta, z uwagi na swój bardzo ogólny charakter, pozwalający na miarkowanie dolegliwości finansowej wymierzanej za określony delikt, nie wyklucza uwzględnienia przez organ - choćby w sposób ukryty - okoliczno-

9 B. Wróblewski, Dyskrecjonalność sędziowska. Studium teoretycznoprawne, Toruń 2004, s. 307.

${ }^{10} \mathrm{Na}$ mocy art. 1 pkt 41 ustawy z 7.04.2017 r. o zmianie ustawy - Kodeks postępowania administracyjnego oraz niektórych innych ustaw (Dz.U. poz. 935) dodano do k.p.a. nowy dział IVa „Administracyjne kary pieniężne”, obejmujący art. 189a-189k. 
ści czynu wskazujących na jego niski bądź wysoki stopień społecznej dezaprobaty także w przypadku innych niż kary pieniężne form sankcji administracyjnych. Takie działanie organu, odwołujące się do powszechnego poczucia słuszności, wbrew obiegowym opiniom wcale nie musi być kwalifikowane jako naruszające zasadę pewności prawa. Organ ma bowiem obowiązek ujawnić okoliczności istotne oraz racje przyjętego toku rozumowania, a podniesione przezeń argumenty podlegają kontroli instancyjnej oraz kontroli sądu administracyjnego. Podstawowym kryterium kontroli powinna być w tym przypadku ocena, czy dokonana przez organ administracji kwalifikacja okoliczności danego przypadku mieści się w granicach swobodnej oceny dowodów, czy też przekracza te granice. Argumentacja organu odwoławczego i jeszcze mocniej - sądu administracyjnego powinna w takim przypadku odnosić się do konkretnych okoliczności świadczących o prawidłowej, to jest zgodnej z zasadami logiki i doświadczenia życiowego, ocenie organu pierwszej instancji albo o uchybieniu tym zasadom.

Takie rozumienie istoty odpowiedzialności administracyjnej pozwala na łagodzenie rygoryzmu konstrukcji odpowiedzialności obiektywnej w sposób wypełniający wymogi zasad płynących z obiektywnych, a więc sprawdzalnych - weryfikowalnych kryteriów, a realizujących wbrew powierzchownemu odczuciu - zasadę pewności i bezpieczeństwa prawa, która odwołuje się w tym przypadku do zagwarantowania jednostce minimalnego standardu ochrony, w celu zachowania istoty zasady sprawiedliwości społecznej, stanowiącej fundament porządku ustrojowego Rzeczypospolitej Polskiej, zgodnie z art. 2 Konstytucji $\mathrm{RP}^{11}$. Ponadto wspomniane ujęcie zasad odpowiedzialności administracyjnej należy uznać za poprawne aksjologicznie, ponieważ uwypukla ono humanistyczne założenie nauki prawa administracyjnego, zgodnie z którym celem prawa, a zwłaszcza prawa administracyjnego, jest i musi być tylko człowiek ${ }^{12}$.

${ }^{11}$ Szerzej P. Tuleja, Komentarz do art. 2 [w:] Konstytucja RP, red. M. Safjan, L. Bosek, t. 1, Komentarz do art. 1-86, Warszawa 2016, s. 223 i n.

12 Z. Duniewska, Wprowadzenie [w:] Dobra chronione $w$ prawie administracyjnym, red. Z. Duniewska, Łódź 2014, s. 8; J. Zimmermann, Aksjomaty..., s. 77. 
Odnosząc te uwagi do tytułowego zagadnienia, wskazać trzeba, że jego prawidłowa analiza powinna opierać się na właściwej interpretacji istoty samorządu terytorialnego. Trafnie podnosi się, co ma ważne znaczenie dla tej problematyki, że atrybut, a zarazem punkt istotny dla odróżnienia samorządu terytorialnego od państwa, zasadza się na samodzielności samorządu. Innymi słowy - o zakresie samorządności rozstrzygają przepisy o nadzorze ${ }^{13}$. Ten wątek rozważań w literaturze przedmiotu znakomicie komponuje się z prostotą ujęcia istoty administracji publicznej jako ogółu działań nakierowanych na dobro wspólne, stanowiące o koherencji tych działań, podejmowanych między innymi przez samorząd terytorialny ${ }^{14}$.

To znaczy, że dobro wspólne determinuje treść działań administracji publicznej, w tym administracji samorządowej, i zarazem stanowi kryterium, którego granice wyznaczają - moim zdaniem - zakres ingerencji organów nadzoru w działalność samorządu terytorialnego. Tak rozumiana koncepcja samodzielności samorządu wyznacza kierunek rozważań przyjętych w tym artykule.

Niewątpliwie pogłębione rozważania dotyczące natury dobra wspólnego przekraczają granice niniejszego artykułu, dlatego też ograniczam się do przyjęcia - jako hipotezy naukowej - takiego rozumienia tego pojęcia, które wskazuje, że dobro wspólne zasadza się na harmonijnym połączeniu dóbr poszczególnych osób tworzących wspólnotę - Rzeczpospolitą Polskę, dla których to osób najwyższym celem, ujmowanym w perspektywie doczesnej, jest budowanie wspomnianej wspólnoty w duchu prawdy, sprawiedliwości, dobra i piękna. Ta koncepcja nawiązuje do tradycji klasycznej, zgodnie z którą celem państwa - poza zabezpieczeniem obywateli przed wzajemnymi krzywdami i ułatwieniem wymiany towarów - jest stworzenie wspólnoty szczęśliwego życia, a więc życia zgodnego z naturą rozumianą generalnie - ujmującą człowieka jako istotę racjonalną oraz zgodną z na-

13 Z. Niewiadomski, Pojęcie administracji publicznej [w:] System Prawa Administracyjnego, t. 1, Instytucje prawa administracyjnego, red. R. Hauser, A. Wróbel, Z. Niewiadomski, Warszawa 2009, s. 29.

14 Z. Niewiadomski, Pojęcie... [w:] System..., red. R. Hauser, A. Wróbel, Z. Niewiadomski, t. 1, Instytucje..., s. 58 i n. 
turą w znaczeniu zindywidualizowanym - odnoszącym się do talentów jednostki oraz jej uwarunkowań ${ }^{15}$.

Trzeba zatem widzieć całościowo system prawny, ponieważ jego odczytywanie, zwłaszcza w odniesieniu do stanowiących elementy tego systemu norm prawnych, przenikających konsekwencje prawnej odpowiedzialności administracyjnej za naruszenie zakazów określonych w prawie administracyjnym, nie może być oderwane od reguł systemowych nakazujących łączne odkodowywanie wszelkich norm, w tym norm sankcjonujących. Niewątpliwie bowiem zasada systemowości wymaga, by za elementy systemu prawa uznawać normy generalno-abstrakcyjne niewyrażone wprost w tekstach aktów normatywnych, a uznawane za logiczną, instrumentalną i aksjologiczną konsekwencję norm wysłowionych w tekstach prawnych $^{16}$.

Inaczej mówiąc, należy mieć na uwadze, że racje systemowe wykładni prawa wymagają przyjęcia operacji myślowej, podczas której nawet językowo zrozumiały tekst prawny, jeśli zawiera normy pozostające w kolizji logiczno-językowej, prakseologicznej lub aksjologicznej z innymi normami obowiązującymi, należy odczytywać modyfikując oczywisty sens językowy terminów występujących w tekście prawnym, tak by określona w wyniku tej wykładni norma nie była wadliwa aksjologicznie, instrumentalnie lub systemowo. Podobnie należy postępować w przypadku stwierdzenia konieczności zastosowania racji funkcjonalnych wykładni, jakie nakazują modyfikację wadliwych norm, które są nieadekwatne do rzeczywistości, sprzeczne $\mathrm{z}$ aktualnymi zasadami ustrojowymi, niesłuszne lub niesprawiedliwe z punktu widzenia społecznie akceptowanego systemu wartości, a jako takie są niewłaściwie oceniane z punktu widzenia zamierzo-

15 J. Nawrot, O. Nawrot, Dobro wspólne w prawie [w:] Wielka encyklopedia prawa, red. A. Bator, J. Zajadło, M. Zirk-Sadowski, t. 7, Teoria i filozofia prawa, Warszawa 2016, s. 89.

16 Szerzej A. Bator, System prawa [w:] Wielka..., red. A. Bator, J. Zajadło, M. Zirk-Sadowski, t. 7, Teoria..., s. 409. 
nych celów regulacji prawnej bądź prowadzą do powstania sprzeczności z celami regulacji prawnej ${ }^{17}$.

Uznać zarazem trzeba, że wolno jest odstąpić od jasnego i niebudzącego wątpliwości rezultatu wykładni językowej, po to, by oprzeć się na rezultacie wykładni systemowej jedynie wówczas, gdy przemawiają za tym ważne racje. Taki zabieg interpretacyjny jest więc uzasadniony, gdy uzyskane znaczenie prowadzi do rażąco niesprawiedliwych rozstrzygnięć bądź pozostaje w oczywistej sprzeczności z powszechnie akceptowanymi normami moralnymi lub gdy prowadzi do niedających się racjonalnie wytłumaczyć konsekwencji z punktu widzenia społecznego lub ekonomicznego ${ }^{18}$.

Pozytywnego odczytania wymaga zatem tytułowa kwestia odpowiedzialności ponoszonej przez radnego za naruszenie zakazu prowadzenia działalności gospodarczej z wykorzystaniem mienia jednostki samorządu terytorialnego. W tym kontekście wymaga w pierwszej kolejności namysłu wyrażona w art. 16 ust. 2 Konstytucji RP zasada, zgodnie z którą samorząd terytorialny bierze udział w wykonywaniu władzy publicznej. Zasada ta wyraża normę wskazującą na istotną rolę samorządu w wykonywaniu imperium - władzy publicznej, co tradycyjnie wiąże się z koniecznością zachowania obiektywizmu i daleko posuniętej troski o prawidłowe zarządzanie majątkiem tych jednostek, wyrażające się zwłaszcza w czytelnym, uczciwym gospodarowaniu składnikami tego majątku. Nie ma więc wątpliwości, że koniecznym warunkiem prawidłowości wykonywania władzy publicznej jest przejrzyste i rzetelne korzystanie z majątku gminy, powiatu czy województwa samorządowego. Stąd potrzebna jest regulacja uniemożliwiająca osobom fizycznym, uczestniczącym - w imieniu tych jednostek - w sprawowaniu władzy publicznej, czerpanie korzyści z mienia tych jednostek. Brak takich unormowań prowadziłby do sytuacji niedopuszczalnych z punktu widzenia zasad uczciwości i rzetelności, które to zasady stanowią rdzeń prawa, wykluczając jego dowolność.

17 Z. Pulka, Racje wykładni [w:] Wielka..., red. A. Bator, J. Zajadło, M. Zirk-Sadowski, t. 7, Teoria..., s. 365.

${ }^{18}$ L. Morawski, Wykładnia w orzecznictwie sądów, Toruń 2002, s. 10. 
Niedająca się usunąć kontrowersja pomiędzy rzetelnym i uczciwym gospodarowaniem mieniem komunalnym a podejmowaniem aktów i innych czynności z zakresu administracji publicznej w imieniu jednostek samorządu terytorialnego uzasadnia więc rozsądny umiar w należytym gospodarowaniu majątkiem tych jednostek.

Pamiętać zarazem trzeba, że kryterium nadzoru nad działalnością samorządu terytorialnego, zgodnie z art. 171 ust. 1 Konstytucji RP, jest tylko zgodność z prawem. Wykluczona jest więc - co do zasady - możliwość władczej ingerencji organu nadzoru uzasadnionej negatywną oceną celowości, rzetelności i gospodarności działań JST, chyba że taka ingerencja mieściłaby się w pojęciu legalności wyznaczonym przez szczególny przepis prawa. Ten sposób ujęcia kryteriów nadzorczych, odczytywanych łącznie z zasadą samodzielności JST, powinien wyznaczać nieprzekraczalne granice ingerencji nadzorczej, uwarunkowanej wartością zasady racjonalności, mającej - jak wskazano wyżej - walor systemowej reguły działania, nadającej zarazem zasadniczy rys prawidłowej wykładni przepisów prawa, w tym prawa administracyjnego.

\section{Racje funkcjonalne i systemowe}

Podkreślenia wymaga, że zgodnie z art. $24 \mathrm{f}$ ust. 1 u.s.g. ${ }^{19}$ radny nie może prowadzić działalności gospodarczej na własny rachunek lub wspólnie z innymi osobami, z wykorzystaniem mienia komunalnego gminy, w której radny ten uzyskał mandat, a nadto nie może on za-

19 Odpowiednio ukształtowano również treść przepisów w odniesieniu do radnych rady powiatu w art. $25 \mathrm{~b}$ ust. 1 u.s.p. i radnych sejmiku województwa w art. 27b ust. 1 u.s.w. Należy jednak zauważyć, że regulacja zawarta w u.s.w. jest w istocie poprawniej ukształtowana, gdyż jednoznacznie rozstrzyga wątpliwości co do tego, że omawiany zakaz nie dotyczy „stosunków prawnych wynikających z korzystania z powszechnie dostępnych usług na warunkach ogólnych oraz stosunku najmu pomieszczeń do własnych celów mieszkaniowych lub własnej działalności gospodarczej oraz dzierżawy, a także innych prawnych form korzystania z nieruchomości, jeżeli najem, dzierżawa lub użytkowanie są oparte na warunkach ustalonych powszechnie dla danego typu czynności prawnych". 
rządzać taką działalnością lub być przedstawicielem bądź pełnomocnikiem w prowadzeniu takiej działalności.

Istotne wskazówki interpretacyjne, pomocne w odczytywaniu tego przepisu, zostały przedstawione przez Trybunał Konstytucyjny ${ }^{20}$. Trybunał wskazał bowiem na podstawowe wymogi płynące z zasady proporcjonalności w kwestii wygaszania mandatu pochodzącego z wolnych wyborów organu gminy, jakim jest wójt (burmistrz, prezydent miasta). Uwagi te trzeba uwzględnić, dokonując wykładni cytowanego przepisu antykorupcyjnego, którego niedochowanie rodzi skutek w postaci wygaśnięcia mandatu radnego (art. 24f ust. 1 w zw. $\mathrm{z}$ art. 98a u.s.g.). Mianowicie Trybunał stwierdził, że wymóg dochowania zasady proporcjonalności powoduje, że przyczyna wygaśnięcia mandatu „musi być na tyle poważna, aby zniweczenie wyniku wyborów (akt demokracji bezpośredniej) było usprawiedliwione, w świetle tego właśnie standardu konstytucyjnego". Zauważyć przy tym należy, że - co do zasady - Trybunał w opisanym orzeczeniu nie zakwestionował samego mechanizmu wygaszania mandatu wójta (burmistrza lub prezydenta miasta) z powodu prowadzenia działalności z naruszeniem ustawowo określonego zakazu, jednakże podkreślił konieczność odczytywania „holistycznego”, to jest z uwzględnieniem kontekstu systemowego, podstaw prawnych omawianego zakazu. To pozwala przyjąć, co wydaje się racjonalne, że taka surowa (daleko idąca) sankcja powinna być stosowana $z$ ostrożnością, umiarkowanie. W tym znaczeniu należy mieć na uwadze, o czym wspomniano wyżej, że jedynie racjonalne (rozsądne) działanie służy budowaniu dobra wspólnego, zaś działanie pochopne, automatyczne, podjęte bez należytego rozważenia istotnych racji systemowych, choćby miało pozór zgodności z prawem, cechy takiej nie spełnia. Co to oznacza? Przede wszystkim to, że wymaganie zapewnienia poczucia sprawiedliwości i słuszności stanowi oparcie dla nierestrykcyjnego odczytywania opisanej normy wynikającej z art. 24 f ust. 1 u.s.g. To, co powinno być zauważone, oddać można w stwierdzeniu zasadności przyjęcia „złotego środka" jako swoistej wskazówki interpretacyjnej odnoszącej się do przywołanych przepisów u.s.g.

${ }^{20}$ Wyrok TK z 13.03.2007 r., K 8/07, OTK-A 2007/3, poz. 26. 
Trafnie afirmuje się takie ujęcie w doktrynie, wskazując, że konstytucyjna zasada demokratycznego państwa prawnego nakłada obowiązek poszukiwaniu pełnej treści prawa również w sferze stosunków samorządowych. Zarówno więc organy administracji, jak i sądy administracyjne powinny odczytywać przepisy samorządowe w sposób odpowiadający duchowi Konstytucji RP. „Oznaczałoby to systemowe podejście do interpretacji norm z zakresu prawa samorządowego, ułatwiające kształtowanie ładu publicznego oraz dające szansę poszukiwania jakiejś uniwersalnej aksjologii”"21.

Takie racje funkcjonalne i systemowe znajdują również oparcie w normach EKSL. W preambule tego aktu stwierdza się, że realizacja zasad demokracji i decentralizacji władzy wymaga ochrony i umacniania samorządu lokalnego, co zakłada istnienie wspólnot lokalnych, posiadających organy decyzyjne wyłonione w sposób demokratyczny, które mają prawo do „szerokiej samorządności”. Dotyczy to wymaganego zakresu autonomii co do kompetencji, a także sposobów i środków, poprzez które te kompetencje są realizowane, i środków koniecznych do wypełnienia tych zadań.

W konsekwencji w jednym z przepisów EKSL (art. 9 ust. 3) wskazano, że nadzór nad wspólnotami lokalnymi należy sprawować z poszanowaniem właściwych proporcji pomiędzy zakresem ingerencji organu nadzorczego a wagą interesów, które organ ten pragnie chronić. Inaczej mówiąc, obowiązkiem państw - sygnatariuszy tego aktu prawa międzynarodowego jest takie ukształtowanie przepisów wewnętrznych, by unikać naruszenia zasady proporcjonalności widzianej z perspektywy znaczenia chronionych spraw dla istoty nadzoru nad samorządem (le respect d'une proportionnalité).

W tym zatem świetle, jak wskazano wyżej, stosowanie sankcji nadzorczej w postaci wygaśnięcia mandatu, będącej - obok utraty biernego prawa wyborczego - najdalej idącą sankcją oddziałującą na sferę tego

${ }^{21}$ M. Zdyb, Źródła prawa powszechnie obowiązującego [w:] Encyklopedia samorządu terytorialnego, red. K. Miaskowska-Daszkiewicz, B. Szmulik, Warszawa 2010, s. $1003-1004$. 
prawa, powinno być traktowane jako środek o charakterze ultima ratio, $\mathrm{z}$ uwagi na w najwyższym stopniu surowy wymiar tej sankcji, na co zwracał uwagę też Trybunał Konstytucyjny w powołanym wyroku ${ }^{22}$.

To pozwala na stwierdzenie, że norma $\mathrm{z}$ art. $24 \mathrm{f}$ u.s.g. powinna być odczytywana tak, by wymusić dokonanie przez organ stosujący prawo zindywidualizowanej oceny okoliczności określonej sprawy, z uwzględnieniem wartości i dóbr chronionych tą normą. Wspomniana ocena powinna odnosić się do całokształtu tych elementów stanu faktycznego i prawnego sprawy, które są istotne z punktu widzenia tychże chronionych wartości, a zwłaszcza celu tego przepisu, jakim jest wykluczenie korupcji wśród radnych, mając na względzie korzystanie przez nich z własności i innych praw majątkowych gminy. Obowiązkiem organu nadzoru jest więc rozważenie charakteru wykonywanej działalności, jej intensywności, a także istotności odczytywanej w odniesieniu do celów tego unormowania.

W tym przypadku zatem interpretacja tekstu prawnego może być ujmowana jako działanie o charakterze optymalizacyjnym, służącym maksymalizacji wartości przedmiotu interpretacji, poprzez wykazanie, że ten tekst - jako zbiór przepisów - jest niedoskonałą formą przejawiania się doskonałej struktury normatywnej, jaką interpretator - w tym przypadku organ nadzoru lub sąd administracyjny - ma obowiązek wydobyć w procesie wykładni. Jak wskazano bowiem, decydujące znaczenie w procesie dekodowania omawianych norm prawnych przyznać należy zasadzie systemowości, która - na poziomie wykładni funkcjonalnej - nakazuje organowi stosującemu prawo (jako interpretatorowi) posługiwać się konsekwentnie celem lub funkcją normy oraz pozaprawnymi ocenami i normami społecznymi. W ten sposób dzięki interpretacji prawniczej omawiany tekst prawny może być odczytany jako mający głębszą i uporządkowaną - zwłaszcza w wymiarze aksjologicznym - strukturę normatywną (systemem norm) ${ }^{23}$.

${ }^{22}$ Zob. pkt 3.7.1 uzasadnienia wyroku TK z 13.03.2007 r., K 8/07.

${ }^{23}$ Z. Pulka [w:] Interpretacja prawnicza jako rodzaj interpretacji filozoficznej, referat wygłoszony na konferencji naukowej pt. Współczesne tendencje rozwojowe teorii i filozofii prawa 2.03.2017 r. w Warszawie. 


\section{Stanowisko orzecznictwa i jego ocena}

Odnosząc się do dorobku orzecznictwa sądów administracyjnych z zakresu rozstrzygnięć nadzorczych w przedmiocie wygaszenia mandatu radnego $\mathrm{z}$ uwagi na naruszenie zakazu prowadzenia działalności z wykorzystaniem mienia komunalnego, zauważyć należy, że dotychczas - raczej jednolicie - przyjmowano restrykcyjną wykładnię wspomnianego przepisu. Sądy zwracają uwagę przede wszystkim na cel art. $24 \mathrm{f}$ ust. 1 u.s.g., który to przepis ma charakter antykorupcyjny oraz ma za zadanie tworzyć odpowiednie standardy wykonywania obowiązków radnego, którego powinna cechować rzetelność i uczciwość. Zdaniem Naczelnego Sądu Administracyjnego treść tego przepisu świadczy o tym, że powierzając jednostkom samorządu terytorialnego uprawnienie do gospodarowania mieniem samorządowym, należało jednocześnie wprowadzić instytucje prewencyjne i represyjne, zmierzające do tego, by uniemożliwić wykorzystanie tego mienia - w sposób bezpośredni lub pośredni - do zaspokojenia interesów faktycznych i prawnych osób fizycznych wchodzących w skład organów JST24. Niewątpliwie celem wprowadzenia wspomnianego unormowania było zapobieżenie podjęciu przez radnych takich działań, które mogłyby podważać autorytet organów gminy - organów władzy publicznej, w których skład wchodzą ci radni, a także uniknięcie sytuacji, które - w ocenie wyborców i opinii publicznej - osłabiałyby zaufanie do prawidłowego funkcjonowania tych organów. Tak ukształtowany mechanizm tego unormowania służy temu, by „z jednej strony zabezpieczyć radnego przed naciskami ze strony jednostek samorządu terytorialnego, zaś z drugiej uniemożliwić wyciąganie korzyści ze sprawowanego mandatu" ${ }^{25}$. Trafnie bowiem podkreślił Trybunał Konstytucyjny, że choć „wpływy funkcjonariuszy gminnych są ograniczone terytorialnie”, to jednak ich nieuczciwe postępowanie jest co najmniej w takim samym stopniu karygodne i po-

24 Wyrok NSA z 18.02.2016 r., II OSK 2759/15, LEX nr 2037476.

${ }^{25}$ Uchwała NSA z 2.04.2007 r., II OPS 1/07, LEX nr 249087; wyrok TK z 23.06.1999 r., K 30/98, LEX nr 37396; uchwała TK z 13.04.1994 r., W 2/94, LEX nr 25114. 
strzegane jako naganne, ponieważ „wyborcom łatwiej jest zauważyć nieuczciwe postępowanie urzędnika gminnego niż wysokiego funkcjonariusza państwowego" 26 .

Mając na uwadze te kwestie, sądy podkreślają bezwarunkowy charakter zakazu przewidzianego w powołanym przepisie, który to zakaz nie jest zależny od tego, czy uprawnienie do korzystania z mienia komunalnego jest elementem stosunku prawno-rzeczowego, jak przykładowo użytkowanie uregulowane w art. 252 i n. k.c., stosunku zobowiązaniowego, jak choćby najem (art. 659 i n. k.c.), dzierżawa - art. 693 i n. k.c., użyczenie - art. 710 i n. k.c. ani od tego, czy korzystanie $z$ tego mienia jest odpłatne, czy pod tytułem darmym, ani od tego, czy radny uzyskuje pożytki (art. 55 k.c.) lub inne przychody z rzeczy stanowiącej składnik mienia komunalnego ${ }^{27}$.

Trzeba zarazem zauważyć, że interpretacja tego przepisu powinna uwzględniać jego bardzo ogólną i bardzo szeroką - w związku z tym - treść. Mianowicie restrykcyjny charakter omawianego przepisu ${ }^{28}$ w połączeniu z grożącą za jego naruszenie sankcją w postaci utraty mandatu radnego - jak wskazano wyżej - należy odczytywać w kontekście innych zasad systemu prawa, w tym zasady samodzielności JST oraz celu wspomnianej regulacji. Ma to oczywiste wytłumaczenie, w refleksji filozoficznej nad prawem już dawno bowiem sformułowano tezę, że to cel jest „twórcą” całego prawa, gdyż cel ma głęboko sięgający wpływ na treść prawa, na kształt prawa oraz na środki

${ }^{26}$ Wyrok TK z 23.06.1999 r., K 30/98, LEX nr 37396.

27 Wyrok NSA z 10.01.2006 r., II OSK 786/05, LEX nr 208945; wyrok NSA z 12.01.2006 r., II OSK 787/05, ONSAiWSA 2006/3, poz. 86; wyrok NSA z 6.04.2006 r., II OSK 23/06, LEX nr 209511; wyrok NSA z 8.08.2006 r., II OSK 753/06, LEX nr 275489.

${ }_{28}$ Zauważyć należy, że w doktrynie wyrażane jest stanowisko, zgodnie z którym przepisy dotyczące nadzoru nad samorządem terytorialnym nie mogą być traktowane jako represyjne instrumenty prawne, stanowią one bowiem gwarancję prawnej ochrony samodzielności JST w tym sensie, że zabezpieczają sytuację prawną tej jednostki samorządowej, która zgodnie z prawem - to jest legalnie - podejmuje działania we wszelkich sferach swojego funkcjonowania, a tym samym te przepisy tworzą swego rodzaju przestrzeń bezpieczeństwa prawnego dla takiej jednostki. Zob. J. Korczak, Konstytucyjne podstawy struktury i funkcji samorządu terytorialnego [w:] System Prawa Administracyjnego, t. 2, Konstytucyjne podstawy funkcjonowania administracji publicznej, red. R. Hauser, Z. Niewiadomski, A. Wróbel, Warszawa 2012, s. 243. 
prawne. To w konsekwencji powoduje, że koniecznie należy „zachować przykazanie proporcjonalności w relacji celu i środka i zakazu nadmiaru"29.

Rozważając zasadność takiej dyrektywy interpretacyjnej, trzeba najpierw zwrócić uwagę na to, że przepis art. $24 \mathrm{f}$ ust. 1 u.s.g., choć szeroko otwiera możliwość naruszenia zakazu w nim wymienionego, to jego treść powinna być odczytywana racjonalnie, a tym samym nie może być ona automatycznie niejako odnoszona do wszystkich przejawów aktywności gospodarczej radnego z wykorzystaniem mienia komunalnego. Zachowanie tego wymogu racjonalności zapewnia dochowanie zasady proporcjonalności, która wymaga, aby ograniczenia konstytucyjnych praw i wolności człowieka i obywatela, w tym prawa osoby do prowadzenia działalności gospodarczej, były przydatne, a zarazem niezbędne do ochrony konkretnej wartości konstytucyjnej, a przy tym nie były to ograniczenia nadmierne.

W przypadku zatem gdy organ stosujący prawo, odczytując literalnie zakaz prowadzenia działalności gospodarczej z wykorzystaniem mienia komunalnego, dojdzie do przekonania, że ograniczenie to ma nadmierny charakter, ma obowiązek - stosując wykładnię prokonstytucyjną - przyjąć takie rozumienie omawianego zakazu, jakie uwzględnia ten wymóg konstytucyjny. Na marginesie zauważyć należy wyjątkowość bezpośredniego stosowania przez organy administracji publicznej Konstytucji RP, a także wykładni w duchu tej Konstytucji RP, wskazując, że tego rodzaju działalność powinna być zasadniczo zastrzeżona dla organów niezawisłych, jak sądy i trybunały. Wydaje się jednak, że ta ogólna uwaga nie stanowi przeszkody do przyjęcia zaprezentowanego wyżej stanowiska, skoro podejmowana jest przez wyspecjalizowany organ nadzorczy, którego rozstrzygnięcie podlega kontroli sądu administracyjnego. Oczywiste jest zarazem, że z uwagi na istotę decyzji podejmowanych w typie administracyjnym stosowania prawa, ak-

\footnotetext{
29 A. Kość, Podstawy filozofii prawa, Lublin 2005, s. 189.
} 
tualność zachowują uwagi L. Leszczyńskiego dotyczące koniecznej „wstrzemięźliwości” w stosowaniu Konstytucji RP przez organy administracji ${ }^{30}$.

W takich właśnie okolicznościach zwrócić należy uwagę na szczególną sytuację radnego, pełniącego jednocześnie funkcję prezesa ochotniczej straży pożarnej - w tej samej gminie, w której radny wykonywał swój mandat. Analizę tej kwestii rozpocząć należy od odniesienia się do pozycji prawno-ustrojowej tych jednostek organizacyjnych, które stanowią jeden z zasadniczych filarów krajowego systemu ratowniczo-gaśniczego, a zarazem - co niezwykle istotne w tej kwestii - odgrywają podstawową rolę w realizacji zadań tego systemu na obszarze gminy. Niewątpliwie przy tym koszty funkcjonowania jednostek ochotniczej straży pożarnej, co wynika z art. 29 i art. 32 ustawy z 24.08.1991 r. o ochronie przeciwpożarowej ${ }^{31}$, pokrywane są ze środków publicznych, a zwłaszcza ze środków gminy. Ta JST ma obowiązek pokryć koszty działania OSP, w szczególności koszty wyposażenia, utrzymania, wyszkolenia i zapewnienia gotowości bojowej. W tym zakresie gminy mogą przekazywać OSP między innymi środki pieniężne, w formie dotacji, służące finansowaniu ich statutowej działalności. Nie budzi również wątpliwości, że - z uwagi na ustawowe cele realizowane przez OSP, służące zapewnieniu bezpieczeństwa na terenie gminy - jednostkom tym mogą zostać przekazane do użytkowania przez gminę nieruchomości, przykładowo w drodze ustanowienia na ich rzecz prawa użytkowania wieczystego gruntu bądź w drodze umowy dzierżawy gruntu. Na marginesie należy jedynie zauważyć, że do realizowania zadań ochrony przeciwpożarowej przez ochotnicze straże pożarne nie jest niezbędne posiadanie prawa własności do gruntu, a tym samym nie jest spełniony w tym przypadku określony w art. 13 ust. 2 w zw. z art. 6 pkt 7 ustawy z 21.08.1997 r. o gospodarce nierucho-

${ }^{30}$ L. Leszczyński, Podstawa decyzji stosowania prawa administracyjnego. Ustalenia walidacyjne [w:] System Prawa Administracyjnego, t. 4, Wykładnia w prawie administracyjnym, red. R. Hauser, A. Wróbel, Z. Niewiadomski, Warszawa 2015, s. 84.

31 Dz.U. z 2018 r. poz. 620 ze zm. 
mościami ${ }^{32}$ warunek przekazania - w drodze darowizny - nieruchomości gminnej na rzecz tego podmiotu ${ }^{33}$.

Interesująca jest w tym kontekście ocena, czy w sytuacji gdy jednostka OSP prowadzi działalność gospodarczą i „korzysta” przy tym z nieruchomości gminnej, taka bowiem nieruchomość została jej przekazana przez gminę, a prezes tej jednostki jest jednocześnie radnym w tej samej gminie, w której siedzibę ma OSP, znajduje zastosowanie art. 98a ust. 2 w zw. z art. 24 f ust. 1 u.s.g. Pozornie wydawać się może, że powyższe argumenty dotyczące pozycji prawnej i zadań realizowanych w gminie przez jednostki OSP są prawnie obojętne dla oceny zastosowania tych przepisów. Ocena ta jednak, moim zdaniem, powinna być co do zasady bardzo wyważona, gdyż nie da się wykluczyć, że w pewnych sytuacjach takie rozumowanie niweczyłoby nie tylko cele ustawy o ochronie przeciwpożarowej, ale także cele zakazu prowadzenia działalności gospodarczej z wykorzystaniem mienia gminy, w tym zakazu zarządzania taką działalnością. Mogłoby to bowiem prowadzić do rygorystycznego i zarazem niezrozumiałego ograniczenia możliwości realizowania zadań gminy na dwóch, niepozostających ze sobą w konkurencji poziomach. Odwołując się do znacznie bardziej ogólnej myśli Świętego Tomasza z Akwinu, wskazać należy, że „działanie ludzkie obraca się około pojedynczych spraw; ale te pojedyncze sprawy można odnieść do dobra wspólnego, przy czym nie chodzi o wspólnotę rodzaju lub gatunku, ale o wspólnotę, którą łączy wspólny cel; a więc chodzi o przyczynę celową, w tym znaczeniu, że dobro ogółu społeczeństwa zwie się celem wspólnym"34.

Zwrócić należy uwagę, że w powyższym przypadku można mówić o istnieniu „wspólnego celu osobowego ludzkiego działania” zarówno osoby sprawującej mandat radnego, jak i osoby zarządzającej jednostką OSP. Celem tym jest bez wątpienia realizacja zadania własnego gminy, jakim jest zaspokajanie zbiorowych potrzeb wspólnoty w za-

32 Dz.U. z 2018 r. poz. 121 ze zm.

${ }^{33}$ Szerzej kwestię tę omówiono w uzasadnieniu wyroku WSA w Rzeszowie z 21.09.2016 r., II SA/Rz 926/16, LEX nr 2097239.

${ }^{34}$ Św. Tomasz z Akwinu, Suma teologiczna. Prawo (I-II, q. 90-105), t. 13, tłum. P. Bełch, Londyn 1986, s. 6. 
kresie porządku publicznego i bezpieczeństwa obywateli oraz ochrony przeciwpożarowej i przeciwpowodziowej. Nie budzi przy tym wątpliwości, że jednostki OSP realizują zadania na rzecz ochrony członków wspólnoty samorządowej nie tylko w zakresie ochrony przeciwpożarowej, lecz również w zakresie zapobiegania innym zdarzeniom niebezpiecznym i klęskom żywiołowym, z zakresu ratownictwa i zapobiegania zagrożeniom ludności. Skoro takie obowiązki spoczywają na tych jednostkach na mocy ich statutów, ale przede wszystkim z mocy obowiązujących przepisów, to prowadzenie przez te jednostki działalności gospodarczej, nawet $\mathrm{z}$ wykorzystaniem mienia gminnego, najczęściej nieruchomości stanowiących własność gminy, przy założeniu, że dochody te przeznaczane są wyłącznie na cele statutowe, nie może być kwalifikowane prosto jako naruszenie zakazu określonego w powołanych wyżej przepisach, gdyż byłoby to nieracjonalne i niesprawiedliwe. Oczywiste jest zarazem, że w przypadku tego podmiotu nie można odgraniczyć wyraźnie sfer działalności polegających na wykonywaniu zadań publicznych od prowadzonej przezeń działalności gospodarczej, właśnie ze względu na jego specyfikę. Jednostki te nie działają dla zysku, a wszelkie uzyskane przychody mogą przekazywać wyłącznie na cele statutowe, które - jak wskazano wyżej - mieszczą się w szeroko rozumianej kategorii wykonywania zadań publicznych, w tym zadań zastrzeżonych do wyłącznej kompetencji gminy. Tym samym podmioty te w istocie uczestniczą w wykonywaniu zadań publicznych, obok, a więc równolegle bądź nawet w zastępstwie wspomnianej jednostki samorządu terytorialnego. Raziłoby więc automatyzmem przyjęcie założenia, ̇̇e każdorazowe stwierdzenie prowadzenia działalności gospodarczej przez jednostki OSP, które korzystają w tym zakresie z majątku gminy, stanowi naruszenie zakazu określonego w art. $24 \mathrm{f}$ ust. 1 u.s.g., w konsekwencji prowadzące do pozbawienia mandatu radnego zarządzającego działalnością OSP. Nie można przecież pominąć, że tego rodzaju działalność gospodarcza służy wyłącznie zapewnieniu prawidłowości wykonywania zasadniczej sfery działalności tych jednostek, jaką jest realizowanie zadań na rzecz bezpieczeństwa publicznego lokalnej wspólnoty samorządowej. Zarazem można uznać, że korzystanie z gminnego mienia, w tym zwłaszcza nieruchomości, jest elementem współudziału gminy w finansowania kosztów działalności OSP, co nie wyklucza przecież uzy- 
skiwania - przy udziale tego mienia - dodatkowych przychodów dla pokrycia tychże kosztów. Byłoby całkowicie nielogiczne twierdzenie, że jednostki te nie mogą prowadzić działalności gospodarczej w takich warunkach, skoro po pierwsze - z punktu widzenia racjonalności wydatkowania funduszy publicznych - byłoby to działanie ze wszech miar pożądane, umożliwiałoby bowiem zmniejszenie obciążeń publicznych na ten cel, a po drugie - realizowałoby istotę zasady pomocniczości.

Istotne jest również, że w odniesieniu do zarządzania podmiotem prowadzącym taką działalność gospodarczą w gruncie rzeczy nie można mówić o czerpaniu zysków przez radnego wykonującego taką funkcję. Regułą jest przede wszystkim, że wykonywanie funkcji prezesa zarządu OSP ma charakter społeczny, gdyż nie wiąże się z uzyskiwaniem jakiegokolwiek wynagrodzenia. To prowadzi do spostrzeżenia, że sprawowanie tej funkcji ma znaczenie z punktu widzenia wsparcia społeczności lokalnej w prawidłowym spełnianiu podstawowych jej obowiązków, do jakich należy nie tylko wykonywanie zadań z zakresu bezpieczeństwa publicznego, mającego wymiar nie tylko społeczny, ale też indywidualny, gdyż prowadzi do wzmocnienia postaw proobywatelskich. Nie można lekceważyć tego typu oddziaływania norm prawnych, gdyż służy ono dobru lokalnej wspólnoty samorządowej, a jako takie w demokratycznym państwie prawnym, opierającym się - jak wynika z preambuły Konstytucji RP - na zasadzie pomocniczości umacniającej uprawnienia obywateli i ich wspólnot, nie mogą być pomijane.

Oznacza to, że pomijanie tego kontekstu normatywnego przy ocenie wystąpienia przesłanek stwierdzenia naruszenia zakazu opisanego w art. $24 \mathrm{f}$ ust. 1 u.s.g. byłoby niezgodne z omawianą dyrektywą interpretacyjną, jaką wyprowadzić można z cytowanego fragmentu Konstytucji RP. W mojej ocenie prowadziłoby to też do naruszenia konstytucyjnej zasady proporcjonalności, która - co wynika z cytowanego art. 9 ust. 3 EKSL - dotyczy także nadzoru nad samorządem terytorialnym, a sprowadza się do konieczności poszanowania należytych proporcji pomiędzy zakresem ingerencji organu nadzorczego a wagą interesów, które organ ten chroni. 
Dodatkowo można się zastanowić, czy z podobną sytuacją nie mamy do czynienia wówczas, gdy radny zarządza działalnością innego podmiotu niż OSP, który prowadzi działalność gospodarczą polegającą w istocie na zaspokajaniu zbiorowych potrzeb lokalnej wspólnoty samorządowej w zakresie określonym w art. 7 ust. 1 u.s.g. - zadań własnych gminy. Wydaje się, że można w sposób ostrożny przyjąć, że w takich sytuacjach nie zawsze musi dojść do naruszenia ustawowego zakazu wykonywania działalności gospodarczej z wykorzystaniem mienia gminnego. Trzeba bowiem mieć na uwadze, że udział w wykonywaniu tych zadań, zastrzeżonych do właściwości gminy, może być oceniany z punktu widzenia współdziałania określonego podmiotu w wykonywaniu określonego zadania publicznego. Poprzez to podmiot prywatny może zatem współuczestniczyć w realizacji zadań gminy, a więc choć - co oczywiste - koszty wykonywania tego zadania obciążają gminę, można rozważać, czy skoro gmina w ten sposób „uwalnia się" od ciążącego na niej obowiązku, to istotne wątpliwości budzi zasadność stosowania w tym przypadku instrumentu nadzorczego związanego $\mathrm{z}$ naruszeniem zakazu $\mathrm{z}$ art. $24 \mathrm{f}$ ust. 1 u.s.g. Niewątpliwie zatem obowiązkiem organów nadzoru jest w tym przypadku wnikliwe zbadanie, na czym polega działalność określonego podmiotu, w celu oceny jej charakteru, w tym zbadania - jak wskazano wyżej - czy przyczyna wygaśnięcia mandatu radnego jest „na tyle poważna, aby zniweczenie wyników wyborów (akt demokracji bezpośredniej) było usprawiedliwione, w świetle tego właśnie standardu konstytucyjnego". Zasadnie bowiem zwrócił uwagę Naczelny Sąd Administracyjny, że automatyzm i rygoryzm w zakresie stanowienia i stosowania przepisów zawierających podstawy wygaśnięcia mandatu radnego prowadzą do podważenia równowagi między prawami wybieranych oraz wyborców a koniecznością osiągnięcia celów, którym służą nakazy i zakazy nakładane na radnych, co z kolei prowadzi do naruszenia konstytucyjnej zasady proporcjonalności ${ }^{35}$. Konieczne jest zatem niebudzące wątpliwości ustalenie i należyte rozważenie wszystkich uwarunkowań związanych z prowadzeniem tej działalności gospodarczej, w tym wagi i okoliczności ewentualnego uchybienia wspomnianemu zakazowi. Dotyczy to, jak wyjaśnił Na-

${ }^{35}$ Wyrok NSA z 20.12.2012 r., II OSK 2818/12, LEX nr 1400020. 
czelny Sąd Administracyjny w wyroku z 7.05.2014 r., II OSK 679/14, LEX nr 1575645, w szczególności sposobu, stopnia i czasu trwania tego naruszenia, dopiero bowiem takie ustalenia pozwalają na wyważenie zasad ochrony interesu publicznego w tym przypadku, gdyż dają podstawę do rozważenia, czy zarządzenie zastępcze wojewody wydane w przedmiocie wygaśnięcia mandatu radnego nie narusza zasady proporcjonalności.

Z tych względów nie podzielam stanowiska przeciwnego, wyrażonego w wyroku NSA z 6.09.2016 r., II OSK 1269/16, LEX nr 2135967, oraz w wyroku NSA z 4.10.2017 r., II OSK 2020/17, LEX nr 2397105. Wskazać bowiem należy, że NSA nie uwzględnił należycie w tych orzeczeniach przywołanych wyżej racji, a w konsekwencji nie uniknął dość powierzchownego potraktowania omawianej problematyki, opierając się w istocie na językowej wykładni powołanego przepisu art. $24 \mathrm{f}$ ust. 1 u.s.g., co należy ocenić jako niewystarczające. Aksjologiczny wymiar analizowanego zakazu prawnego nakazuje wszechstronne odczytanie zawartej w nim normy prawnej w kontekście zasady systemowości oraz zasady proporcjonalności. Wydaje się zarazem, że NSA pominął w tym przypadku argumenty, których istotą jest prokonstytucyjna wykładnia przepisów, w procesie dokonywania której są pomocne orzeczenia Trybunału Konstytucyjnego, w tym przywołany wyrok z 13.03.2007 r., K 8/07, ponieważ zawierają one istotne wskazówki interpretacyjne w tej kwestii. Trzeba bowiem zastanowić się, czy przyjęte przez NSA w tych orzeczeniach rozumienie powołanego przepisu jest do pogodzenia $z$ funkcją i modelem ochrony praw jednostki realizowanej przez sądy administracyjne, którym przyznaje się kompetencję do bezpośredniego stosowania Konstytucji ${ }^{36}$.

Jako inspirujący ocenić natomiast należy pogląd wyrażony w wyroku NSA z 11.01.2018 r., II OSK 2889/17, LEX nr 2449129. Sąd przeprowadził w tym orzeczeniu pogłębioną analizę dorobku judykatury w omawianym zakresie i wskazał, że miarkowanie stosowanej sankcji stwierdzenia wygaśnięcia mandatu przedstawicielskiego po-

${ }^{36}$ Zob. R. Hauser, J. Trzciński, Prawotwórcze znaczenie orzeczeń Trybunału Konstytucyjnego w orzecznictwie Naczelnego Sądu Administracyjnego, Warszawa 2010, s. 46 i n. 
przez odwołanie się do zasady proporcjonalności powinno być uzasadnione szczególnymi okolicznościami rozpoznawanej sprawy. To, zdaniem NSA, oznacza, że w zakresie, w jakim nie da się skutku w postaci wygaszenia mandatu uzasadnić celem regulacji, „przepis [art. $24 \mathrm{f}$ ust. 1 u.s.g.] wyłącza spod [określonego w nim] zakazu korzystanie przez radnego z mienia gminnego na zasadach pełnej powszechności”.

To prowadzi do wspomnianego wyżej wniosku, że za niezasadny uznać trzeba automatyczny i rygorystyczny sposób odczytywania normy dekodowanej z art. $24 \mathrm{f}$ ust. 1 u.s.g. Aprioryczne przyjęcie założenia o całkowicie represyjnym charakterze tej normy, bez uwzględnienia przywołanego kontekstu systemowego, kształtowanego również zasadą samodzielności gminy, prowadzi do błędnego odczytywania tej normy. Jedynie uwzględnienie "umiarkowanego” rozumienia tego przepisu, spełniającego zarazem przesłankę racjonalności, pozwala na wypełnienie treścią ducha powołanych unormowań konstytucyjnych oraz prawnomiędzynarodowych.

\section{Zakończenie}

Omawiana problematyka może być ujmowana także z etycznego punktu widzenia. Zasadnie bowiem akcentuje się, że bez zgody co do podstaw aksjologicznych i normatywnych na uznawanym w społeczności ludzkiej poziomie nie jest w stanie należycie działać samorząd terytorialny. Dlatego też konieczna jest rewitalizacja moralności zarówno w wymiarze indywidualnym, jak i społecznym, przejawiająca się zasadniczo w dowartościowaniu godności osoby ludzkiej. Niewątpliwie bowiem, skoro idea samorządu wyraża się między innymi w sprawowaniu władzy w imieniu mieszkańców, w trosce o jawność życia publicznego i należyte rozporządzanie mieniem JST, to funkcjonowanie samorządu zakłada wartości i normy społeczne, a także moralne oraz środki ich realizacji. Konieczne jest zatem wychowanie do wartości uniwersalnych, mających charakter stałych drogowskazów aksjologicznych i normatywnych, które opierają się relatywizacji, ponieważ stanowią swoiste pewniki moralne. Te powinności wynikają 
ostatecznie z godności człowieka, a charakteryzują się tym, że jako wartości powinnościowe ukazują określone działania, jak choćby akty nadzorcze czy nawet orzeczenia sądu administracyjnego, z punktu widzenia oceny, czy działania te „są takimi, jakimi powinny być” ${ }^{37}$.

Dlatego też stanowisko wyrażone w dyskutowanych orzeczeniach NSA uznać trzeba za zbyt daleko idące $z$ uwagi na niezachowanie wymogów zasady systemowej proporcjonalności, nakładającej na organy stosujące prawo, w tym na sądy administracyjne, obowiązek przemyślanego wyważenia granic ochrony konkurujących w tym przypadku wartości konstytucyjnych, jakimi z jednej strony są wolność gospodarcza i samodzielność gminy, a z drugiej - konieczność rzetelnego i uczciwego sprawowania mandatu radnego gminy. Wskazówką interpretacyjną w tym zakresie powinna być również przywołana wyżej konstytucyjna zasada dobra wspólnego, którą należy rozumieć, uwzględniając to, że dobrem wspólnym powinno być tylko takie dobro, które jest „rzeczywistym dobrem całej społeczności i zarazem każdego człowieka”. To prowadzi do wniosku, że jeśli działanie ludzkie ma mieć charakter ważny nie tylko dla jednostki, ale także dla społeczności, musi być podyktowane prawem - w znaczeniu ius, a nie lex, a więc regułą rozumu praktycznego decydującą o realnym sposobie realizowania dobra. Dobrem tym może być jedynie „dobro człowieka jako człowieka, jako aktualizacja potencjalności osobowych, pojęta jako analogiczna tożsamość celu". Wspomniane dobro można osiągnąć tylko poprzez „ujrzenie-rozumienie” oraz dobór osobistych środków służących realnemu uzyskaniu dobra, które jest celem każdej jednostki - w tym przypadku radnego - oraz celem wspólnoty, jaką w tej sytuacji stanowi gmina ${ }^{38}$.

Odmienna od przyjętej w niniejszej pracy interpretacja wspomnianych przepisów prowadzi do paradoksalnej konkluzji, że ochrona dobra prawnego, jakim jest uczciwość i rzetelność w zarządzaniu oraz

${ }^{37}$ Zob. J. Mariański, Moralność w społeczeństwie współczesnym [w:] Encyklopedia..., red. K. Miaskowska-Daszkiewicz, B. Szmulik, s. 408-409.

${ }^{38}$ M.A. Krąpiec, Dobro wspólne i prawa człowieka [w:] M.A. Krąpiec, Suwerenność - czyja?, Lublin 2001, s. 170. 
dysponowaniu mieniem publicznym, może uniemożliwiać prowadzenie działań, w tym również działań uczciwych i rzetelnych, w oparciu o przepis prawa pozytywnego (lex). Powstaje w ten sposób ekwiwokacja pasująca do pojęcia błędnego koła, gdzie jako przesłankę dla określonego rozumienia powołanego przepisu, mającego charakter restrykcyjny (mylnie utożsamiany z obiektywnym - skoro rozumienie to jest oparte tylko na jednej z możliwych i w dodatku kontrowersyjnej interpretacji tego unormowania), przyjmuje się przesłankę o nieomylności interpretatora tekstu prawnego, zawoalowaną umownym (i zawodnym) założeniem nieomylności prawodawcy.

\section{Bibliografia:}

Bator A., System prawa [w:] Wielka encyklopedia prawa, red. A. Bator, J. Zajadło, M. Zirk-Sadowski, t. 7, Teoria i filozofia prawa, Warszawa 2016

Duniewska Z., Wprowadzenie [w:] Dobra chronione w prawie administracyjnym, red. Z. Duniewska, Łódź 2014

Hauser P., Trzciński J., Prawotwórcze znaczenie orzeczeń Trybunału Konstytucyjnego w orzecznictwie Naczelnego Sądu Administracyjnego, Warszawa 2010 Ingarden R., Książeczka o człowieku, Kraków 1987

Człowiek i jego decyzje, red. K.A. Kłosiński, A. Biela, Lublin 2009

Korczak J., Konstytucyjne podstawy struktury i funkcji samorządu terytorialnego [w:] System Prawa Administracyjnego, t. 2, Konstytucyjne podstawy funkcjonowania administracji publicznej, red. R. Hauser, Z. Niewiadomski, A. Wróbel, Warszawa 2012;

Kość A., Podstawy filozofii prawa, Lublin 2005

Krąpiec M.A., Wprowadzenie do filozofii, Lublin 2008

Leszczyński L., Podstawa decyzji stosowania prawa administracyjnego. Ustalenia walidacyjne [w:] System Prawa Administracyjnego, t. 4, Wykładnia w prawie administracyjnym, red. R. Hauser, A. Wróbel, Z. Niewiadomski, Warszawa 2015

Mariański J., Moralność w społeczeństwie współczesnym [w:] Encyklopedia samorządu terytorialnego, red. K. Miaskowska-Daszkiewicz, B. Szmulik, Warszawa 2010

Morawski L., Wykładnia w orzecznictwie sądów, Toruń 2002 
Nawrot J., Nawrot O., Dobro wspólne w prawie [w:] Wielka encyklopedia prawa, red. A. Bator, J. Zajadło, M. Zirk-Sadowski, t. 7, Teoria i filozofia prawa, Warszawa 2016

Niewiadomski Z., Pojęcie administracji publicznej [w:] System Prawa Administracyjnego, t. 1, Instytucje prawa administracyjnego, red. R. Hauser, A. Wróbel, Z. Niewiadomski, Warszawa 2009

Pulka Z., Racje wykładni [w:] Wielka encyklopedia prawa, red. A. Bator, J. Zajadło, M. Zirk-Sadowski, t. 7, Teoria i filozofia prawa, Warszawa 2016

System Prawa Administracyjnego, t. 6, Podmioty administrujące, red. R. Hauser, A. Wróbel, Z. Niewiadomski, Warszawa 2011

Św. Tomasz z Akwinu, Suma teologiczna, Londyn 1986

Tuleja P., Komentarz do art. 2 [w:] Konstytucja RP, t. 1, Komentarz do art. 1-86, red. M. Safjan, L. Bosek, Warszawa 2016

Wartości w prawie administracyjnym, red. J. Zimmermann, Warszawa 2015

Wróblewski B., Dyskrecjonalność sędziowska. Studium teoretycznoprawne, Toruń 2004

Zdyb M., Źródła prawa powszechnie obowiązującego [w:] Encyklopedia samorządu terytorialnego, red. K. Miaskowska-Daszkiewicz, B. Szmulik, Warszawa 2010

Zimmermann J., Aksjomaty prawa administracyjnego, Warszawa 2013 